(2)

\title{
The Bondage and Subsequent Agency of Violet in Toni Morrison's Jazz
}

\section{Melanie A. Marotta}

\begin{abstract}
In Toni Morrison's Jazz, the character Violet Trace has difficulty adapting to her life in the City (that is, Harlem) after she moves there from the South. This essay examines the influence of the urban space on the transformation of Violet's identity over the course of the novel, which occurs in three stages, each associated with her relationship to a key female character. The first stage occurs during Violet's journey to Harlem and is coloured by the death of Dorcas, her husband's lover. The second stage features Alice, Dorcas's aunt, who helps Violet to locate and process her pain. The final stage of Violet's transformation occurs under the influence of Felice, Dorcas's friend, who empowers Violet to release her past and reform her identity. Together, these women come to represent community for Violet and play a vital role in Violet's transformation and healing.
\end{abstract}

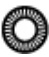

\section{Introduction}

In Jazz, Toni Morrison's character, Violet Trace, has difficulty adapting to her life in Harlem (the City) after she moves to the North from the rural South. This article reveals the influence of urban space on the female community and how both aid in the transformation of Violet's identity. This transformation occurs in three stages, each associated with Violet's relationship to a key female character in the novel: Dorcas, her husband's lover; Alice, Dorcas's aunt; and Felice, a young woman in the community and a friend of Dorcas's. In a letter addressed to Black women contained in "A Knowing So Deep" (1985), after noting that Black women are "the rim of the world - its beginning," Morrison writes:

Hell's twins, slavery and silence, came later. Still you were like no other. Not because you suffered more or longer, but because of what you knew and did before, during, and following that suffering. No one knew your weight until you left them to carry their own. But you knew. You said, "Excuse me, am I in the way?" knowing all the while that you were the way. You had this canny ability to shape an untenable reality, mold it, sing it, reduce it to its manageable, 
transforming essence, which is a knowing so deep it's like a secret. In your silence, enforced or chosen, lay not only eloquence but discourse so devastating that "civilization" could not risk engaging in it lest it lose the ground it stomped. (32)

Even though Morrison penned this letter more than a decade before Jazz, she describes a woman whose resemblance to Violet, later called Violent by many in Harlem, is striking. Here, Morrison cites two aspects of adversity, "slavery and silence," as important determiners of identity. She continues to develop the notion that Black women have the ability to disturb societal constructs.

In 1906, Violet and her husband, Joe Trace, arrive in Harlem as part of the African American Great Migration from the rural South to the urban North. In a discussion of Jazz and the City, Dale Pattison observes:

Traveling to Harlem with Joe, Violet embodies both the traumatic experience of the Great Migration, when African Americans left behind their slave pasts and journeyed to northern cities, as well as the more personal loss of her mother, Rose Dear, who commits suicide in response to the brutal economic realities of the post-bellum South. (132)

Pattison's observations show the context of Violet and Joe's arrival in the City: like many other African Americans from the rural South, they flee "after raving whites had foamed all over the lanes and yards of home," going North for freedom, for employment, for improved income, and for the "glamour" (Morrison, Jazz 33). For Violet and Joe, while the move away from home to the city is necessary for survival, it also fosters feelings of alienation. Maria-Sabina Draga Alexandru discusses Morrison's City as a character itself, and how its power to control the characters' actions - to confine them instead of offering them freedom - is felt by many (202). To some African Americans in the South, the North appears as a flawless beacon of liberty until they arrive and experience it for themselves. 
Violet experiences a transformation in her identity, and her environment, particularly the City, aids in her changes. The first stage of Violet's life is comprised of her time in the South, her journey to Harlem, and the death of Dorcas Manfred, her husband's lover. During this period, Violet is influenced by Joe, True Belle (her grandmother), and the City: her sense of self gives way to Joe's projection of masculinity, to True Belle's desires, and to the City's accelerated pace. In the next stage of her transformation, Violet resembles the silent female that Morrison depicts in the letter referenced earlier in this essay; she causes upheaval to Harlem society but also turns inwards towards her feelings of self-doubt and loneliness. It is during this period that she meets Alice Manfred, Dorcas's aunt, who aids Violet in finding and releasing her pain, thus reforming her identity. Violet's third life occurs under the influence of Felice, Dorcas's friend. Once the duo meets, Violet can let go of her infatuation with Dorcas and pass on her knowledge of stagnation to Felice. These women become Violet's community, thereby aiding in the transformation of her identity.

\section{The First Life of Violet}

One of the most pertinent pieces of information regarding Violet's identity comes not from Violet herself but from Joe. Before Violet and Joe's past is first mentioned, the unnamed narrator highlights Joe asserting agency over his life. According to the narrator, it is Joe who initiates the affair with Dorcas and who chooses the moment of his and Violet's departure to New York. In the narrator's account of the events that lead to their departure for the City, Violet ensures she and Joe are in close proximity to one another - she obtains work that enables her to be physically near him - but it is Joe who decides when they should go north. Joe, who is enamoured with the country, gives no indication of why he desires to leave the South. His acts of power over his identity are undercut by the fact that Violet selects Joe for marriage and that he has no interest in the marriage other than as a means to leave the rural South. In the initial stage of her life, Violet is the one who is confident and has power, but, once they reach New York, their 
positions alter. In the South, Joe faces discriminatory practices; in particular, he is subjected to and exploited by the sharecropper economic structure. Joe suffers from the white patriarchal ideals placed upon him, but his feelings of powerlessness also stem from his mother's abandonment, from his and Violet's treatment by Caucasians in the South, and from the violence in the City that is directed towards African Americans.

When Joe takes over as narrator, he shows that sharecropping has ill effects on his selfhood. He then tells the reader that, when he arrives in the City, he is attacked. By relating this information, he attempts to dispel the stories of glory he heard while in the South. Hence, the portrayal of place is shown to be significant as an influential factor in identity development. After Joe describes his success in the City at one of his past jobs, he notes, "In 1925 we all had it made. Then Violet started sleeping with a doll in her arms. Too late. I understood in a way. In a way" (129). At this point, Joe reflects on his life, on Violet's behavior, and on his treatment of her: he admits he has treated Violet badly, subsequently stating, "I'll never get over what I did to that girl" (129). Unfortunately, the damage to Violet's identity has already been done when he makes this assertion. Both bell hooks and Barbara Christian reveal that, for African American men, moving to the North is not gratifying because "black men lost status" when they did so (hooks 91). According to Christian in a discussion of Ann Petry's Harlem Renaissance novel The Street, black men are unable to fulfil their role as protector and provider in the North; this fact is clearly displayed by Joe when he narrates his experiences in the City (Black 11). For my examination, this digression into Joe's identity and behaviour is essential because he exists throughout Violet's three stages of transition and because he significantly contributes to her insecurity through his emotional distance from her and his affair with Dorcas.

Joe does not hold Violet responsible for his behaviour, nor does he blame himself for the change in Violet's behaviour, which lends credence to hooks's assertion that "[m]ost black men remain in a state of denial, refusing to 
acknowledge the pain in their lives that is caused by sexist thinking and patriarchal, phallocentric violence that is not only expressed by male domination over women but also by internecine conflict among black men" (102). Unhappy, Joe attempts to fill his emptiness with Dorcas, a young woman with whom he effectively communicates. The narrator observes that his affair, which he carries out in the same building where he and Violet reside, occurs when Violet is away at work. Here, place (the apartment) is not freeing, instead appearing as a space of confinement for Violet and Joe. When Joe is with Violet, he refuses to be physically active; indeed, the only time that Joe appears to physically move about in his apartment is after Dorcas leaves. To Violet, Joe is dismissive and neglectful. When he informs Malvonne about his affair and tries to rent a room from her for his rendezvous, he tells her the reasons for his affair: "Violet takes better care of her parrot than she does me. Rest of the time, she's cooking pork I can't eat, or pressing hair I can't stand the smell of. Maybe that's the way it goes with people been married long as we have. But the quiet. I can't take the quiet. She don't hardly talk anymore, and I ain't allowed near her" (49). To Malvonne, Joe discloses his negative feelings about Violet; subsequently, Malvonne is the person who tells Violet about the affair. After Dorcas's funeral, Violet's behaviour shows that she has become insecure. Whereas her inquiries lead to her attempt at becoming Dorcas, her actions show she believes she is inferior to Dorcas.

Violet's dream of living in the City is originally due to her grandmother's influence. True Belle is a former slave and subsequent free woman, who arrives at Violet's home because white landowners are evicting her daughter, Rose Dear, and granddaughter from their home. Rose Dear refuses to depart and, instead, commits suicide. From the stories that True Belle tells Violet and the events that occur after her arrival, "the biggest thing Violet got out of that was to never never have children," a fact that she later regrets (102). True Belle encourages the journey to the city because she refuses to permit her family to stay in an area where work is scarce and poorly compensated. Because Violet is unsure of her 
future, she "could neither stay where she was nor go away," so True Belle pushes her towards opportunity and agency (102). Lisa Cade Weiland observes that the families in a number of Morrison's texts are "matriarchal" and that the women are the authority figures, as they are in Violet's family (114). Christian, too, recognizes the influential nature of the family in Morrison's novels, and, symbolically, nearly all of the families, particularly Violet's, Felice's, and Dorcas's, are headed by women (New 64). When Joe gives the details of his and Violet's life together, he makes it appear as if Violet suffers in the City. The narrator, however, describes Violet not only eagerly accepting her new circumstances in the City but also being very successful after she arrives.

Upon arrival in the City, Violet flourishes. The narrator describes Violet, not Joe, as the character that has agency. When she leaves the South, Violet temporarily escapes her lack of confidence and embraces freedom from restraint. Even though there were hardships for African Americans in Harlem during the migration, Violet transcends them by moving with the City instead of against it. The narrator notes, "Nobody says it's pretty here; nobody says it's easy either. What it is is decisive, and if you pay attention to the street plans, all laid out, the City can't hurt you" (8). Repeatedly in Jazz, the narrator shows that, if people move against the grain in the City or remain stagnant, life becomes problematic. Violet is depicted early in her city life as decisive, "a snappy, determined girl and a hardworking young woman, with the snatch-gossip tongue of a beautician. She liked, and had, to get her way" (23). Not only does Violet move out of service; she becomes self-employed in a thriving industry during the early twentieth century. Violet also aggressively ensures they have a new apartment, while Joe depicts obtaining a new residence as a dehumanizing struggle. Violet is successful and proactive as she approaches customers in order to secure their business, noting that the services she offers are of better quality than those given in a licensed beauty parlour. Importantly, she rises in position and becomes an independent businessperson; however, by being unlicensed, Violet is, in fact, an outsider. Over 
time, she begins to suffer from what the narrator describes as "private cracks" in her self (22).

Before Violet's second life begins, the narrator discloses that Violet releases her hold on her power, gives in to Joe's stagnation, and submits to her loneliness in the City: "Violet sat down in the middle of the street. She didn't stumble nor was she pushed: she just sat down" (17). Violet changes after being in the City and succumbs to its chaotic yet freeing influence; however, as the narrator points out, those that travel to the City become one of many. After Violet and Joe arrive in the City, "dancing all the way" (32), they become lost within it. In an interview with Elissa Schappell, Morrison discusses the notion that "true agency" can be obtained within the city as long as history is neither "forgotten" nor confining; instead, the past should educate, and people should "forget what ought to be forgotten" ("Toni" 83). History places what Morrison calls a "straightjacket" on Joe (83), and Violet too becomes stagnant, reverting to uncertainty and then loneliness. The rural community - her family and the neighbours who bring Rose Dear's evicted household goods to sustain them - no longer exists in the City. The close-knit community from the rural South gives way to the faceless masses of Harlem. In her interview with Angels Carabi, Morrison describes the feelings of African Americans when they reach Harlem: "There was the thrill of seeing yourself in large numbers, again developing a sort of black town, Harlem. [...] [O]ne of the most interesting things was a freedom to fall in love, to own your body, to be immoral" ("Nobel" 92). Because Violet and Joe become involved with the City, their marriage and their identities suffer. Morrison observes in the interview that, when Violet and Joe enter the City, the restraints have lessened and the risks have increased (92): "And in the beginning when they first arrive, and twenty years later when they and the City have grown up, they love that part of themselves so much they forget what loving other people was like - if they ever knew, that is" (Jazz 33). In this excerpt from the novel, Violet and Joe are not named; however, it is clear that the narrator describes Violet and Joe's behaviour. 
When Violet sits down in a street, people concerned with her welfare and those who are unnerved by her behaviour come to discover the cause of her distress.

Violet, who is heading towards the fragmentation of her identity that constitutes her second life, refuses the aid of the faceless, nameless masses. According to the narrator, in the City "hospitality" must be judged, as there are those who wish to help while others wish to harm (9). Morrison's unnamed narrator continues to reveal that, if a person is not successful in this endeavour, "you can end up out of control or controlled by some outside thing like that hard case last winter" (9). In reference to Morrison's novels Sula and Song of Solomon, Christian notes, "Like many oral storytellers, Morrison spins tales about how the characters' conduct of their lives is connected to their community's value system" (Black 48), a concept that may be applied to Violet, seeing that she is wary of the help offered. While in the street, Violet refuses kindness, a glass of water, but accepts the protection offered by the masses when a police officer desires to have her arrested. The populace informs the policeman that Violet is in the street because she is "tired" (17), and they subsequently take her out of the street, where she eventually wakes from her stupor. In her first life, Violet has no friends, no community, and a shell of a relationship with Joe. She is essentially alone. By refusing the aid of the masses at first, she reveals that she incorporates the ideology of the City into her self. When she accepts their help, however, Violet shows that she desires to become part of the community.

The incident occurs before Dorcas's funeral and her attempted kidnapping of the baby. It is the loss of human interaction, of closeness, that Violet mourns and attempts to replace once she discovers Dorcas. Even though work is available in the country, the narrator reveals that, in the City, there is more time to fill, and some women desire to do so with "rest" (16). Morrison's narrator observes, "they wouldn't like it. They are busy and thinking of ways to be busier because such a space of nothing pressing to do would knock them down" and, in a sense, this is what happens to Violet (16). Violet's emptiness must be satiated. Once she 
discovers Dorcas's presence, she becomes obsessed; this infatuation fills the emptiness with which her lack of rural community has left her ("Toni" 83).

\section{The Second Life of Violet}

Violet's fixation rests not only on Dorcas - in particular what music she listens to and her appearance - but also on Joe and his lifestyle. The event that begins the second stage of Violet's life is her attack on Dorcas's body at the funeral, which instantiates her obsession with Dorcas and her fixation on Joe occurs then as well. Aoi Mori states, "Trying to fit into urban life, they [those that migrated] deceive themselves that the glaring city lights appease their loneliness" (321). Once the affair is discovered and Violet is unable to carry out her task at the funeral, she attempts to have an affair of her own. When she discovers that she is not fulfilled, she then tries to take care of Joe. Violet's behaviour is not out of revenge but out of feelings of emptiness. Violet loses her purpose once she reaches the City; Mori reveals that she and Joe "lose their passion and interest in life" once separated from the country and are, in fact, "less active" in the City (323). Both of Mori's points are fascinating since the unnamed narrator centres much of the City discussion on the fact that, in this new area, people have a zest for life that appears frenetic in nature (323). Women newly arrived in the City find that, since places are closer, life is more convenient and the time they have to themselves has increased. When Violet reaches the City, she has many activities to occupy her, but she is not fulfilled: "Anyway, Joe didn't pay Violet or her friend any notice. Whether she sent the boyfriend away or whether he quit her, I can't say. [...] Violet's next plan - to fall back in love with her husband - whipped her before it got on a good footing" (5). In her second life, Violet proceeds to take care of Joe's body, but no conversation ensues, which the narrator calls "[a] poisoned silence" (5).

Anne-Marie Paquet-Deyris calls attention to Morrison's City as "the capital of black America"; more importantly, "the sense of place was essentially defined by what it could no longer be, and by what it wasn't quite yet" (219). Paquet- 
Deyris's observation makes clear that the City has a specific identity of its own, which is carnivalesque, individual, and reliant on its populace. This characterization is relevant for my examination as the City transfers its identity onto its inhabitants. When Violet reaches the City, she is in tune to the movement and the identity of the place, but, as the narrator observes, she loses her identity over a period of twenty years. In her second stage, she tries to find herself first through another relationship and then through taking care of Joe; when she is unsuccessful in her endeavours, she comes to the conclusion that she is flawed. Violet is primarily depicted as stagnant inside of her apartment, separated from the movement of the City. Once Violet no longer functions in tandem with the City and because of her self-imposed isolation, her behaviour is affected and she becomes an outsider. In her first stage, Violet is described as making comments that are out of place amid normal conversation - as when she tells Miss Haywood that the time of her granddaughter's hair appointment is at "[t]wo o'clock if the hearse is out of the way" or when she tells Joe about the numbers that she is to play in the lottery and asks him, "[W]ho is that pretty girl standing next to you?" (24). It is clear that Violet is out of phase with the City - her thoughts and identity are fragmented. Because of her stagnation, Violet, as the narrator states, is "knock[ed] down" (16). Aware that her statements are out of place, Violet loses her voice and becomes self-conscious. When she has these outbursts, they are ignored by witnesses; Joe's reaction to Violet's increasing voicelessness, however, is clearly more unsettling: "Over time her silences annoy her husband, then puzzle him and finally depress him. He is married to a woman who speaks mainly to her birds" (24). These birds, as substitute children, exist to fill Violet's emptiness. Notably, she releases them as the novel opens after she returns from Dorcas's funeral.

The novel begins with Violet's attack on Dorcas's body at her funeral. The masses, unforgiving, then physically and socially place her outside of the community. For example, Morrison's narrator reveals that, when the Salem 
Women's Club meets, they discuss Violet and, instead of voting to give her money to assist her, they decide that "only prayer - not money - could help her now" (4). The group leaves Violet to her own devices, thereby sending her away from the community in Harlem. The narrator observes that Violet's disruption of the funeral ceremony causes her to lose many of her customers and seek other female outsiders in order for her to work. At this point, Violet financially supports the household, as Joe does not regularly go to work. Importantly, the narrator notes that the women for whom Violet now works "don't care what she done" (14). These women appear willing to accept her services; however, this is not a community that Violet wishes to join. For instance, in a conversation with an unnamed character, Violet informs her that "women wear me down," thereby continuing to aggressively blame Dorcas and "little hungry girls" for Joe's affair (14). The woman tries to advise Violet regarding the affair, but Violet refuses to acknowledge her views. While Violet disagrees with her, she also absorbs some of the latter's modern views regarding women and men. In fact, Violet then "wonders if she isn't falling in love with [Dorcas] too" (15). Significantly, she also begins to see Dorcas as flawed: for example, Violet first admires Dorcas's hairstyle but then alters her opinion, seeing it as problematic and needing cutting. Violet's identity is fluctuating, and, as a result, so is her outlook about Dorcas.

Importantly, Violet does not have a female community in the City until she begins to visit Alice. Alice does not want to associate with Violet because she sees her as the woman who intrudes on and violently disrupts the funeral act. Morrison discloses in her foreword to Jazz that Dorcas, like Sethe in Beloved, is based on an actual person whose photograph is included in James Van Der Zee's The Harlem Book of the Dead (Foreword xv). According to Morrison, the premise of the novel which is Dorcas's death - is inspired by a photograph of a young female in a coffin who was shot at a party by her male partner and chooses to die (xv-xvi). The narrator opens the novel by stating, "When the woman, her name is Violet, went to the funeral to see the girl and to cut her dead face they threw her to the 
floor and out of the church" (3). The "they" that is referenced is the nameless, faceless populace of the City who not only physically removes Violet from the funeral but also renames her "Violent" (3).

In her discussion of trauma in relation to Violet, Laurie Vickroy observes that, because Violet refuses to come to terms with her unsuccessful pregnancies and the loss of her mother, she overcompensates by caring for others, namely her clients and her birds (107). Evelyn Jaffe Schreiber also discusses trauma in relation to Violet; however, she states that Morrison's character has actively chosen not to have children rather than, as Vickroy states, miscarried (113). Notably, the evidence supports both conclusions: Violet miscarries three times while in the South and elects to not have children once she arrives in the City because "citylife would be so much better without them" (Morrison, Jazz 107). When Violet is unable to counteract her feelings of emptiness, she acts out; the fractures in Violet's identity reveal themselves as "she has trouble identifying [these acts] as her own" (Vickroy 107). Vickroy continues to delve into Violet's behaviour, noting that "Violet loses connection with her life, as if she is watching it from a distance. She experiences an extreme self-division, identifying this behavior from which she wants to dissociate as done by a double of herself" (108). Violet is unable to accept that her behaviour is abnormal or criminal because her identity has broken into pieces.

When Violet visits Alice, she keeps her hat on while she removes the rest of her outerwear. She tells Alice, "I'm having trouble with my head" (Jazz 80). On one hand, Violet wants to give in to her stagnation and remain in a downward spiral, while, on the other hand, she desires change. When she goes to the funeral with the knife, her behaviour shows agency: she tries to harm Dorcas's exterior, which she believes is better than hers. Violet desires information about Dorcas, but it is superficial, from the music she likes to the type of lipstick she wears. Violet even attempts to dance as Dorcas does, but she is unable to quash her feelings of inferiority and fill her emptiness with Dorcas. Morrison's narrator reveals that, 
after Violet's relationship with a lover and her ministrations to Joe in attempts to fill the void fail, "she decided to love - well, find out about - the eighteen-yearold whose creamy little face she tried to cut open even though nothing would have come out but straw" (5). It is not the substance that Violet desires regarding Dorcas but that which makes Dorcas appear alive. Violet needs Alice's help to discover the motive for her behaviour, but, more importantly, she wants Dorcas to fill the void of loneliness.

During a moment in the novel when the narrator is disclosing background information regarding Violet and Joe's Southern past, the narrator also reveals that Violet and Joe do not have children. In the City, where the satisfaction of the individual and the community is crucial, Joe and Violet try to adapt to city culture, ridding themselves of rural ideology and forgetting the past (Grewal 119). The narrator documents Violet's three miscarriages and Joe's reaction to them, characterized as "more inconvenience than loss" (Morrison, Jazz 107). Even though neither Violet nor Joe wants offspring, Violet's subsequent behaviour when she comes into contact with children shows that her feelings of emptiness, of loneliness, partially stem from the absence of children in her life. Not only does Violet physically burn a customer while doing her hair because she becomes involved in watching the customer's child; she also "bought herself a present; hid it under the bed to take out in secret when it couldn't be helped" (108). Violet is lost in her loneliness, in her need to have children.

Violet tries to fill her void with her birds, which tell her that she is loved. She even tries to steal a baby because he temporarily makes her content and because "Joe will love this" (20). Members of the community witness Violet's attempt at kidnapping the child, and, while the majority of witnesses believe Violet's story that she never intended to take the child, others believe this assertion to be false. Morrison shows that Harlem contains a community, but there is not a feeling of closeness between the characters as there was in Violet's rural home. It is this closeness, this emotional attachment, that Violet seeks and 
finds in Alice and Felice later in her life. The doll that Violet buys herself and hides, the birds, and the baby she attempts to take are her attempts at stopping her feelings of emptiness and isolation. When she tries to kidnap the baby, she earnestly believes the child is going to solve the problems that she and Joe have in their marriage and as individuals. Violet's fixation on Dorcas is another substitute like the baby and the birds. Only when Violet meets Alice and they communicate their problems to one another is Violet able to heal, therefore changing her identity.

Regarding Jazz, Deborah Barnes argues that the novel "shows that 'success' won at the expense of cultural isolation, abandonment, or alienation [...] is success won too dear. Morrison's fiction demonstrates historical fact: that cultural estrangement and loss too often accompany the African American's social, economic, and political 'progress'" (284). Barnes notes that Morrison's works often include characters that remove themselves from their communities and suffer as a result. Violet's isolation contributes to her identity's fragmentation. Without her family and neighbours, her community in the South, Violet is alone and discontent $(284-85)$. She satiates herself by replacing her familial and rural community first with a lover; then with Joe, the birds, the doll; and then with Dorcas, thereby filling up the emptiness. Violet is also disconnected from her urban female community. She tries to become an urbanite, in particular by becoming a successful working female but, being alone, Violet's identity cannot positively change. Violet's female community is necessary in order for her identity to evolve.

One of the most important aspects of change and reformation to the female identity is Violet's obtaining a voice. In "The Transformation of Silence into Language and Action," Audre Lorde discusses her health crisis and reveals the harmful nature of "silence": "My silences had not protected me. Your silence will not protect you" (40-41). Violet chooses to distance herself from others and to protect herself through the use of silence. For example, when she finds herself 
making statements that appear odd, Violet decides to retreat into silence. Violet's act of attacking Dorcas's body is both her attempt at destroying that which makes her feel inferior and her cry for help to her community. While the community, appalled at her behaviour, places her in bondage through the use of the nickname, Violent, Alice also appears shocked but soon accepts the presence of Violet in her life.

According to Lorde, the "cause of silence" is "fear" (42), which is clearly depicted in Jazz when the narrator refers to Violet and her "cracks" (22). Violet's feelings of insecurity lead her to ask Alice for Dorcas's photograph, which is put in a place of honour on the mantelpiece in her apartment. At night, both Joe and Violet rise and peer at the photograph, and, importantly, both of them say the name Dorcas aloud. Violet, who suffers from a loss of agency and insecurity, looks at the photograph and sees "[a]n inward face - whatever it sees is its own self. You are there, it says, because I am looking at you" (12). Violet clearly feels insignificant. According to the narrator, Joe does not work, and Violet must charge lower rates for her hairstyling services because she is not licensed. Violet is, therefore, an outsider, as is Alice. Both women are fearful, albeit for different reasons.

Alice's fear results from the City, specifically the morality and the discriminatory behaviour of its inhabitants. Like Violet, Alice is trapped in a silent world, but Alice's silence has more to do with what she believes is decent behaviour. She wants silence and loathes the sounds of the community revelling in a time where a lack of restraint is commonplace. When Violet first appears at Alice's home, Alice makes Violet voiceless by refusing to speak to her. Violet and Alice are similar characters: each attempts to fulfil herself and to discard her loneliness through the act of fixation (on Dorcas and on housework particularly), and each ends up discovering the other as a source of friendship. Gurleen Grewal states that Alice discovers "that she is not far removed from the embarrassing woman she calls 'Violent.' She is forced to recognise the humanity of Violet, a 
member of the black urban working class. Eventually the two women find a steadying companionship, each seeing in the other a reflection of her own grieved self" (123). Even though, in the beginning, Alice wants nothing to do with Violet, she does have an interest in her. To the community and to Alice, also an outsider who despises the revelry that occurs in the City, Violet is an oddity. For Alice, Violet is also "the star of her niece's funeral. The woman who ruined the service" (Morrison, Jazz 75). The narrator notes that, given Violet's appearance at the funeral, Alice is angry and fearful; however, her feelings dissipate. Chad Jewett documents the formation of the narrative voice in Jazz and analogizes it to modal jazz:

Jazz [...] begins with a basic melodic riff, Joe's murder of Dorcas and his wife Violet's slashing of the dead girl's face at the funeral. Morrison tells the story itself within a few sentences, a few bars of music, before in fact freeing the narrative from any set notation. By referring to the opening compressed plot prompt as a riff, I am stressing the compactness and memorability of the prompt. (446)

Through this comparison, Jewett emphasizes the impact of these events - not Dorcas per se but the actions stemming from the events surrounding her death on the characters' development throughout the novel. Through repetition, like with Jewett's "riff," Violet is able to gain Alice's attention. Because Violet repeatedly leaves notes for Alice, the latter's anger slowly ebbs away.

Slowly, Alice accepts Violet's company, as she, too, has emptiness in her life. As Violet labels Dorcas, Alice labels Violet and includes her in the groups of African Americans she titles "dangerous" and "embarrassing" (Morrison, Jazz 79). The instantaneous conversation that erupts between Alice and Violet once she admits Violet into her home is productive. Lorde continues her discussion of silence and fear with the assertion, "But most of all, I think, we fear the visibility without which we cannot truly live" (42). No one sees Violet and Alice for who they actually are. After Dorcas's death and subsequent funeral, Violet becomes 
"Violent," and Alice is the aunt of the murdered Dorcas. Once the duo confronts one another, their visibilities alter. When Alice asks Violet, "What could you want from me?" (80), Violet appears tired once again and asks only for a seat. Violet and Alice reveal information to each other: for example, Violet tells Alice about her behaviour as a child, and Alice reveals Dorcas's true nature. It is interesting that the more visits Violet makes, the closer and more personal they become. For instance, Alice asks Violet if Joe is abusive towards her and then proceeds to mend her clothing for her. Violet, who has previously been silent regarding her feelings of inferiority with regards to Dorcas, voices her reason for reaching out to Alice. Lorde continues, "In the transformation of silence into language and action, it is vitally necessary for each one of us to establish or examine her function in that transformation and to recognize her role as vital within that transformation" (43). One of the most telling statements regarding Violet's state of mind comes from Violet herself: she informs Alice that she is there not only because she needs to rest, "to sit down somewhere," but also because "I wanted to see what kind of girl he'd rather me be" (82). Violet acknowledges her pain to Alice, sharing with another female the violence against her identity that she experiences as a result of Joe's affair. What appears to be a verbal attack by Alice towards Violet's identity, an act to which Violet responds, is in actuality a release of pain by both parties (Grewal 118-37). Their words show that Alice and Violet blame each other for the affair; however, by verbalizing their pain, each woman releases that which holds her in a stagnant position, and this release brings them closer together.

After their heated exchange, the narrator gives an account of another visit to Alice by Violet, thereby showing the close relationship that has developed between the two. The narrator notes that when Alice interacts with Violet, who is still being called "Violent" here, there is no façade. With Alice, Violet feels comfortable enough to begin releasing the societal restraints regarding her behaviour: "When Violet came to visit (and Alice never knew when that might be) something opened up. [...] Alice sighed a little sigh, amazed at herself as she opened the door to the 
only visitor she looked forward to" (83). The women teach one another lessons about life: to Violet, Alice is the voice of reason, and, to Alice, Violet is the voice of modern urban reality. When Alice declares Violet's customers immoral and nothing like her, Violet informs Alice, "They're just women, you know. Like us" (84). Importantly, Christian notes that, for African American females, "the intersections of sexism and racism" are crucial to the understanding of their identities ("But" 42). Alice adamantly separates herself from the "new" African American female. The issues prevalent for the formulation of the self for African Americans during this period were not only about upliftment but also about freedom. Unfortunately, Alice does not want to understand that women's identity formation is shifting. Applying Lorde's statement to Violet and Alice, the "transformation" - that is, the verbalization of the pain which is, in itself, an act of agency - enables the person who is expressing herself to locate her identity and herself within her community (Lorde 43). When Violet admits to Alice that she believes Dorcas to be her "enemy" (85), Alice informs her that she is incorrect in her assumption, and then, significantly, the narrator launches into Alice's story, which is filled with her past pain (Grewal 119). Alice's story shows that she is similar to Violet; her husband previously leaves her for another woman, and she, too, desires revenge against the unnamed female. Once Violet and Alice have their final emotional release, it is then that Violet contemplates the form her life has taken while sitting in the drugstore. She subsequently transforms and reforms her identity.

In an interview with Jane Bakerman, Morrison discusses Sula, specifically the moment when Nel discovers the affair between Sula and Jude: "When I wrote it, I thought it was absolutely beautiful, purely distilled pain" ("Seams" 58). Morrison has the ability to create moments of extreme emotional distress (as well as moments of release) in her novels. Both Violet and Alice come alive again once they laugh at a minor incident, specifically Alice's mishap with the ironing. Once again, location becomes symbolic for Violet. When the section containing Violet's 
story opens, she appears sitting alone in a drugstore after leaving Alice's home contemplating the fragmentation of her identity: "[S]he sat in the drugstore sucking malt through a straw wondering who on earth that other Violet was that walked about the City in her skin; peeped out through her eyes and saw other things" (89). Once Violet experiences a moment of catharsis with Alice, she becomes aware of her actions after her fragmentation and can then reform her identity. Even though Violet sits in a location that symbolizes the alienation that the City can cause, the space is not one to which these characters have an emotional attachment. While having her malt, she remembers a moment of levity with Alice in her home. When Violet initially arrives at Alice's, they release their frustrations and pain to one another: specifically, Violet reveals her confusion about her relationship and the City, to which Alice responds by calling her "Mama" (110). According to Grewal, "The chief attribute of the city is that it marks the break from a repressive past" (125). The point that Grewal makes is that, while Harlem signifies a place where African Americans are free and can obtain a better standard of living, it is also understood that, in Jazz, characters cannot flee from the truth (125). When Alice involuntarily makes her utterance, Violet contemplates her mother and her suicide. Both females then become silent, a silence which Alice breaks. Clearly, both females fear ending up as their mothers. This incident is as cathartic for them as their moment of laughter.

After Violet's memories of that morning are interrupted by the narrator describing her sitting in the drugstore - and noting that the housework with which she usually fills her emptiness is not done - the narrator observes that Violet has gone to visit Alice instead. The duo enjoys spending time together so much that they become distracted, until Violet notices that the iron has damaged the clothing; Alice then voices an expletive, and they erupt into laughter. Lorde reveals, "it is necessary to teach by living and speaking those truths which we believe and know beyond understanding. Because in this way alone we can survive, by taking part in a process of life that is creative and continuing, that is 
growth" (43). The silence has ceased, and the pain of the past dissipates. Violet is then reminded of her grandmother's laughter upon seeing the children in the emptiness of the house when she first arrived and the relief that the family felt as they joined in: "Violet learned then what she had forgotten until this moment: that laughter is serious. More complicated, more serious than tears" (113). When she exits the drugstore, her identity has been reformed because the memory of her family's laughter enables Violet to remember happiness. Symbolically, when she leaves, she "noticed, at the same moment as that Violet did, that it was spring. In the City" (114). By incorporating both pain and pleasure, Violet's emptiness subsides, as does the fragmentation of her identity (Grewal 119). Violet is then able to enter into the third stage of her life, where she can release Dorcas (shown through her returning the photograph to Alice), and repair her marriage.

\section{The Third Life of Violet}

Before Violet's third stage, Joe's story is told, as is that of Dorcas. Both Violet and Joe must release their pain if their marriage is to be successful, so they rejoin the City's masses (Grewal 119). Since Violet's stagnation subsides through her agency, she can re-enter the City. After her transition, Violet appears outside in the City. In an interview with Nellie McKay about Tar Baby, set on a remote island estate, Morrison discusses her choice of locale:

I wanted them to be in an ideal place. What makes such vacation spots ideal is the absence of automobiles, police, airplanes, and the like. When a crisis occurs, people do not have access to such things. The crisis becomes a dilemma and forces the characters to do things that otherwise would not be required of them. All the books I have written deal with characters placed deliberately under enormous duress in order to see of what they are made. (417)

Because Morrison continues to follow this pattern in Jazz, Violet's identity fragments under the weight of her emptiness. When Violet appears in the novel again, after the section devoted to Joe's and Dorcas's lives, she is shown on the porch of her apartment building without a coat - and, significantly, "she didn't 
care" that she was not wearing one (197). Border imagery here appears as a barrier between confinement and freedom: Violet is on the brink of change, which is symbolized by her being seated on the porch. Morrison's narrator notes, "But the space where the photo has been was real. Perhaps that's why, standing there on the porch, unmindful of her behind, she easily believed that what was coming up the steps toward her was another true-as-life Dorcas, four marcelled waves and all" (197).

Dorcas's story is told by her friend, Felice, only once Dorcas has died. Violet is disturbed at Felice's arrival, and the narrator notes that Violet's identity is, once again, becoming unhinged. When Felice tells her story, she relates the events of the party where Joe killed Dorcas. In a sense, Dorcas's murder and her actions beforehand are lessons for both Violet and Felice; as Grewal notes, the women must "acknowledge the traumatic nature of the past" (119). Dorcas's life is a cautionary tale that Violet absorbs into her identity. Once Violet learns that Dorcas has no substance, she releases her, thereby helping Joe to do so as well. Felice observes that, when she enters the apartment, the couple now interacts: after Violet brings Joe food, he makes an effort to verbally and physically make contact with her. Both Violet and Joe come to terms with their flaws and their pain, and they are able to pass this information along to Felice, a member of their community.

Morrison's novel is about self-acceptance, self-absolution, and loneliness. The City, though it contains a large populace, does not foster emotional attachments easily. Accordingly, even when sex is represented in the novel, it is never an act of lust but an act of closeness to another being. Violet and Joe attempt to pass on their knowledge and experiences to Felice and to aid her in releasing her pain; this is signified by the act of burying her opal ring with Dorcas. Felice's mother steals this ring from Tiffany's, and, like Violet and Joe, Felice must come to terms with a mother in the past (Grewal 119). Grewal notes, "By the novel's end, the wounded triad of Violet, Joe, and Dorcas - a configuration of unworked-through trauma - 
is replaced with the healing threesome of Violet, Joe, and Felice" (133). Felice does not cry for Dorcas until she has spent a great deal of time with Violet and Joe in the apartment. In an act of agency for herself, for Joe, and for Felice, Violet tells Felice that, in order to successfully function, power over one's life is required. Once that is obtained, Felice is able to cry over the loss of her friend. Morrison closes the novel with stories about Violet and Joe: in particular, the narrator shows the pair content with the past, their new community, and the City. In the end, Violet is no longer stagnant, filling her time with that which symbolizes life: birds, music, and others' children. Violet does not attempt to erase her feelings of emptiness; rather, she satisfies herself with life.

\section{Conclusion}

When telling Violet's story, Morrison expertly dramatizes Violet's desire to remove herself from poverty, from loneliness, and from her mother's death. So that they may survive, Violet and Joe must escape stagnation. When Vesper County, Virginia is described in the novel, the image of the tree immediately appears, symbolizing the peace and simplicity of the rural area and the connection of the people to an African past (given its resemblance to the African palm). Once Violet and Joe reach the City, their lives are no longer the same, as some concepts do not translate in the City. According to Barnes, "Joe and Violet when they leave the rural, agrarian South for the urban, industrial North [...] encounter major discrepancies in social reality. They soon discover that their relationships with people and things change radically from one place to another" (287). One aspect of the country does survive, and that is the concept of community. Unfortunately, the community in the City is not as emotionally close as it is in the rural area. Notably, however, despite showing the harmony of the community in the South, Morrison refrains from sentimentalizing this rural space.

Pattison contemplates Jazz's physical spaces and their influence upon the characters: "Embracing an intimate relationship with (and within) the city for Morrison's black characters involves redefining and relocating their interior and 
exterior selves, a process that would have been impossible in a Jim Crow South committed to ossified antebellum notions of black identity" (131). As Pattison notes, the South offers confinement for the body and a release that may only be achieved once the urban space has been reached. Conclusively, the rural space offers communal closeness with others, something not presented to Violet until after she shows her vulnerability to Alice. Some City dwellers want to place Violet into bondage, specifically to label her for not conforming to the norm and to distance themselves from her once her identity begins to fracture. Pattison continues:

Morrison's novel suggests that, bearing these traumas [from her past], Violet should be read not as exceptional but as representative of the African American experience of migration and cultural dislocation at the turn of the century. Entering the mechanized, disciplined world of the northern city, Violet must refashion her private self as a means of entering the public domain of urban life. (132)

In order to heal and reform her wounded identity, Violet needs Alice's physical presence and emotional support. She thus succeeds in transforming her identity by adapting to her circumstances and embracing female community.

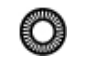

\section{Works Cited}

Alexandru, Maria-Sabina Draga. "Love as Reclamation in Toni Morrison's African American Rhetoric." European Journal of American Culture, vol. 27, no. 3, 2008, pp. 191-205.

Barnes, Deborah H. “Movin' on Up: The Madness of Migration in Toni Morrison's Jazz." Toni Morrison's Fiction: Contemporary Criticism, edited by David L. Middleton, Garland, 1997, pp. 283-95.

Christian, Barbara. Black Feminist Criticism: Perspectives on Black Women Writers. Teachers College, 1997. 
-. "But What Do We Think We're Doing Anyway: The State of Black Feminist Criticism(s), or My Version of a Little Bit of History." Black Feminist Cultural Criticism, edited by Jacqueline Bobo, Blackwell, 2001, 38-52.

-. New Black Feminist Criticism, 1985-200o. Edited by Gloria Bowles, M. Giulia Fabi, and Arlene R. Keizer, U of Illinois P, 2007.

Grewal, Gurleen. Circles of Sorrow, Lines of Struggle: The Novels of Toni Morrison. Louisiana State UP, 1998.

hooks, bell. Black Looks: Race and Representation. South End, 1992.

Jewett, Chad. "The Modality of Toni Morrison's Jazz." African American Review, vol. 48, no. 4, 2015, pp. 445-56.

Lorde, Audre. "The Transformation of Silence into Language and Action." Sister Outsider: Essays and Speeches by Audre Lorde. 1984. Crossing, 2007, pp. 40-44.

Mori, Aoi. "Embracing Jazz: Healing of Armed Women and Motherless Children in Toni Morrison's Jazz." CLA Journal, vol. 42, no. 3, 1999, pp. 320-30.

Morrison, Toni. Foreword. Jazz, by Toni Morrison, Vintage, 2004, pp. xv-xix.

-. "An Interview with Toni Morrison." Interview with Nellie McKay, Contemporary Literature, vol. 24, no. 4, 1983, 413-29.

-. Jazz. 1992. Vintage, 2004.

-. "A Knowing So Deep." What Moves at the Margin: Selected Nonfiction, edited by Carolyn C. Denard, UP of Mississippi, 2008, 31-33.

—. "Nobel Laureate Toni Morrison Speaks about Her Novel Jazz." Interview with Angels Carabi, Toni Morrison: Conversations, edited by Carolyn C. Denard, UP of Mississippi, 2008, pp. 91-97.

-. "The Seams Can't Show: An Interview with Toni Morrison." Interview with Jane Bakerman, Black American Literature Forum, vol. 12, no. 2, 1978, pp. 5660.

-. "Toni Morrison: The Art of Fiction." Interview with Elissa Schappell, Toni Morrison: Conversations, edited by Carloyn C. Denard, UP of Mississippi, 2008, pp. 62-90. 
Paquet-Deyris, Anne-Marie. "Toni Morrison's Jazz and the City." African American Review, vol. 35, no. 2, 2001, 219-31.

Pattison, Dale. "Building Intimacy: The Erotic Architectures of Toni Morrison's Jazz." Critique: Studies in Contemporary Fiction, vol. 58, no. 2, 2017, 129-45.

Schreiber, Evelyn Jaffe. Race, Trauma, and Home in the Novels of Toni Morrison. Louisiana State UP, 2010.

Vickroy, Laurie. Trauma and Survival in Contemporary Fiction. U of Virginia P, 2002.

Wieland, Lisa Cade. "Family." Toni Morrison Encyclopedia, edited by Elizabeth Ann Beaulieu, Greenwood, 2003, 114-18.

Melanie A. Marotta received her $\mathrm{PhD}$ in English from Morgan State University in Baltimore, Maryland. She is a Lecturer in the Department of English and Language Arts and an editor for the Museum of Science Fiction's Journal of Science Fiction. Originally from Ontario, Canada, her research focuses on twentieth-century and contemporary African American Literature, the American West, science fiction, and ecocriticism. 